\title{
EFFECTS OF ANTIMICROBIAL AGENTS ON THE ACTIVITY AND SURVIVAL OF AEROMONAS HYDROPHILA AND NITRIFYING BACTERIA IN VITRO
}

\author{
G.C. OKPOKWASILI" and FLORENCE N. ELEKE \\ Department of Microbiology, University of Port Harcourt, P.M.B. 5323, Port Harcourt, \\ Nigeria
}

(Received: 30 August 1996; accepted: 07 November 1997)

\begin{abstract}
The effects of four common antimicrobial agents (chloramphenicol, gentamycin sulphate, omethylene blue, neomycin sulphate) on the activity and survival of Nitrosomonas, Nitrobacter and Aeromonas hydrophila isolates from a tilapia fish pond were evaluated. This was done by monitoring growth on agar plates and changes in $\mathrm{pH}$, ammonia, nitrite, nitrate and dissolved oxygen concentrations of culture water in experimental flasks during treatment. Ammonia and nitrite oxidations were inhibited by $13.3 \mathrm{mg} / \mathrm{l}$ of chloramphenicol, $66.7 \mathrm{mg} / \mathrm{l}$ of neomycin sulphate and $8 \mathrm{mg} / \mathrm{l}$ of methylene blue. Gentamycin sulphate $(5.3 \mathrm{mg} / \mathrm{l})$ had no effect on nitrification. With the exception of gentamycin sulphate, all the other antimicrobials inhibited the growth of Nitrosomonas, Nitrobacter and Aeromonas hydrophila during treatment.
\end{abstract}

Key words: Aeromonas hydrophila, antimicrobials, fish ponds, nitrifying bacteria, Nitrobacter, Nitrosomonas.

\section{INTRODUCTION}

Species of genera Nitrosomonas, Nitrobacter and Aeromonas are considered autochthonous inhabitants of aquatic environments. They have been isolated in both polluted and non-polluted waters. ${ }^{1}$ These nitrifying bacteria are of critical importance in nitrogen cycling in nature. The concentration as well as form of nitrogenous compounds are among the factors influencing the productivity of an aquatic environment. Microbial populations in tilapia culture pond have been reported to have wide substrate specificity. ${ }^{2}$ Nitrification is carried out exclusively by microbes, the most important of which are the chemolitotrophic nitrifying bacteria typified by the ammonia-oxidizing genus Nitrosomonas and nitrite oxidizing genus Nitrobacter. These organisms are considered to be the most important nitrifiers but their appearance may simply represent successful competition with other nitrifiers such as Aeromonas hydrophila which can reduce nitrate aerobically by assimilatory reduction via nitrite to ammonium ions. ${ }^{3}$ Aeromonas hydrophila has been implicated in several diseases of fish such as haemorrhagic septicaemia, haemolytic bleeding, ${ }^{4}$ brown patch disease of the skin ${ }^{5}$ and fin rot. ${ }^{6}$ The role of Aeromonas hydrophila in mortalities of stressed fish has also been reported. ${ }^{6,7}$

\footnotetext{
$*$ Corresponding author.
} 
Antibacterial agents that have found wide usage in fish culture are chloramphenicol, erythromycin, potassium permanganate, gentamycin sulphate, neomycin sulphate, nifurpirinol and methylene blue. ${ }^{7-11}$ Administration of most of these agents in feed or culture water system is the most practical method of treating systemic bacterial diseases of fish. Hence the question arises as to the effect of these agents on nitrifying bacteria in a fish pond. It has been found that certain antibacterial compounds can inhibit or arrest oxidation of ammonia and nitrite in closed fresh water culture systems $\mathrm{s}^{10,12}$ and in culture flasks inoculated with nitrifying bacteria. ${ }^{11}$ The inhibition of nitrification in closed culture systems leads to the accumulation of ammonia and/or nitrite substances that can be highly toxic to aquatic animals. ${ }^{13}$

No published work so far has associated Nitrosomonas and Nitrobacter with any form of disease in both plants and animals. However, when bacteriological filtration is interrupted by chemotherapy, the resulting deterioration in water quality may be more lethal than the pathogens to the diseased animals. ${ }^{14}$ This study was undertaken to determine the effect of four commonly used antimicrobial agents on the activity and survival of Nitrosomonas, Nitrobacter and Aeromonas hydrophila isolated from tilapia fish pond in order to assess their effect on the cycling of nitrogen in the environment.

\section{METHODS AND MATERIALS}

Sample Collection: Studies were conducted with pond water samples collected at Duru Fish Farms located on the bank of Njaba River at Awo-Omamma, Oru Local Government Area of Imo State, Nigeria where approximately 6000 young active tilapia were reared in fresh water. Also disinfection of the pond water with antimicrobial agents is carried out twice in a year. Pond water samples were analysed for the following physico-chemical parameters: $\mathrm{pH}$, ammonia, nitrite, nitrate and dissolved oxygen (DO) concentrations. Measurements were made using Direct Reading Engineering Laboratory(DR-EL/S) Hach kit. ${ }^{15}$

Culture Studies: Serial dilutions of the samples were aseptically carried out at the University of Port Harcourt using sterile physiological saline $(0.85 \% \mathrm{w} / \mathrm{v}$ $\mathrm{NaC1}$ ) as diluent before plating on appropriate media. Each flask contained the three bacterial species. Nitrifying bacterial counts were estimated on agar plates treated with mineral salt medium containing either ammonium sulphate or sodium nitrite for Nitrosomonas and nitrite oxidizing Nitrobacter respectively. ${ }^{16}$ Presumptive Aeromonas hydrophila was enumerated on RS agar ${ }^{17}$ and medium of Kaper et al. (1979). Plates were incubated following the spread plate technique. Inoculated plates were incubated at $30^{\circ} \mathrm{C}$ for 4 days. Reported plate counts were those lying within the range 30-300 colony forming units (cfu). Colonies were randomly selected from each medium, isolated and restreaked on fresh selective media plates to purify. Pure cultures were then maintained at $4^{\circ} \mathrm{C}$ 
as stock cultures for further tests on the selective media. Characterization of the isolates was performed ${ }^{19}$ and involved cell micromorphology, Gram reaction, motility, oxidase, catalase, urease, $\mathrm{H}_{2} \mathrm{~S}$ production, citrate utilization, indole, methyl red-Voges Proskauer(MR-VP) tests, oxidation/fermentation of glucose and decarboxylase tests.

Survival Studies: Survival studies of pure cultures of the three bacterial isolates on the antimicrobials (shown below) were carried out in culture flasks.

Antimicrobial Dosage (mg/l)

Neomycin sulphate

Chloramphenicol

Methylene blue

Gentamycin sulphate
66.7

13.3

8.0

5.3

The experimental methods similar to those described ${ }^{12,20}$ were employed. Nine 1-litre Erlenmeyer flasks were each filled with $500 \mathrm{ml}$ of pond water, sterilized by filtration through a $0.22 \mu \mathrm{m}$ pore size membrane (Millipore Corp) and autoclaved at $121^{\circ} \mathrm{C}$ for 30 minutes. They comprised four sets of two flasks per set and one control flask. Pure culture suspensions in sterile water were made separately in sterile $50 \mathrm{ml}$ flasks with each of the bacterial species isolated from the tilapia pond water. The bacterial suspensions were aseptically serially diluted to $10^{-4}$ and the counts of this dilution determined by plating onto agar plates containing selective media and then adjusting to $10^{6}$ cells $\mathrm{ml}^{-1}$. One millilitre of the bacterial suspension with cell concentration of $10^{6} \mathrm{ml}^{-1}$ was inoculated into $500 \mathrm{ml}$ of each of a set of two flasks. No organisms were added to the control flask.

The antimicrobial agents at concentrations frequently used for the treatment of diseases of fresh water aquarium fishes ${ }^{8}$ were added directly to the sterilized pond water in culture flasks as single dosages on day zero. Each of the four antimicrobials was added to one set of two flasks and no antimicrobials to the control set. The concentrations of $\mathrm{NH}_{4}^{+}-\mathrm{N}, \mathrm{NO}_{2}^{-}-\mathrm{N}, \mathrm{NO}_{3}^{-}-\mathrm{N}$ and $\mathrm{pH}$ were all determined immediately before the bacterial suspension and antimicrobials were added on day zero and on alternate days thereafter for the duration of the experiment which lasted 21 days.

All the flasks were capped with cotton wool bungs and aerated by shaking at $120 \mathrm{rpm}$. On alternate days, $0.1 \mathrm{ml}$ of water from each flask was plated on selective medium for survival studies. Colonies per plate were counted after incubating at $30^{\circ} \mathrm{C}$ for $48 \mathrm{~h}$. Bacterial activity was monitored by determining changes in the $\mathrm{pH}$ and concentrations of $\mathrm{NH}_{4}^{+}-\mathrm{N}, \mathrm{NO}_{2}^{-}-\mathrm{N}, \mathrm{NO}_{3}^{-}-\mathrm{N}$. Approximately $150 \mathrm{ml}$ of water removed for sampling were replaced once weekly with 
newly mixed sterilized pondwater containing appropriate concentrations of the antimicrobials.

Statistical analysis: Mean bacterial counts were subjected to $\log _{10}$ transformation and stepwise multiple linear regressions were calculated using the IBM Computer (Model-30). The mean values thus obtained in the analysis were compared using F-test to evaluate the statistical significance.

\section{RESULTS}

The effects of the various antimicrobials on the chemical parameters measured over an 18-day period following treatment in experimental flasks are given in Fig. 1.

The filter-sterilized pond water quality in all the flasks prior to treatment was:

$$
\begin{array}{ll}
\mathrm{pH} & 6.73 \pm 0.01 \\
\mathrm{NH}_{4}^{+}-\mathrm{N} & 0.40 \pm 0.01 \mathrm{mg} / \mathrm{l} \\
\mathrm{NO}_{2}^{-}-\mathrm{N} & 0.09 \pm 0.01 \mathrm{mg} / 1 \\
\mathrm{NO}_{3}^{-}-\mathrm{N} & 11.10 \pm 2.00 \mathrm{mg} / \mathrm{l}
\end{array}
$$

(mean \pm standard deviation, $\mathrm{n}=10$ ).

In control systems no significant changes in water quality were observed since they were not inoculated with bacteria. The $\mathrm{pH}$ gradually declined from 6.73 on day zero to 6.70 on day 18 . The $\mathrm{pH}$ values in flasks treated with antimicrobial agents did not differ significantly ( $p>0.05)$ from those of the controls.

Treatment of flasks with gentamycin sulphate $(5.3 \mathrm{mg} / \mathrm{l})$ did not significantly alter water quality. Flasks treated with neomycin sulphate $(66.7 \mathrm{mg} / \mathrm{l})$ resulted in water quality changes significantly different from the control $(p<0.05)$. Total ammonia-nitrogen rose to a peak of $1.38 \mathrm{mg} / \mathrm{l}$ on day 8 and then rapidly decreased (Fig.1). Nitrite-nitrogen rose immediately during treatment to a peak of $2.5 \mathrm{mg} / \mathrm{l}$ on day 8 and rapidly decreased to $0.15 \mathrm{mg} / \mathrm{l}$ on day 18 . Nitrate-nitrogen fell immediately after treatment to $6.0 \mathrm{mg} / \mathrm{l}$ on day 2 , remained relatively stable until day 10 when it began rising rapidly reaching $13.0 \mathrm{mg} / \mathrm{l}$ on day 18 .

Treatment with methylene blue $(8.0 \mathrm{mg} / \mathrm{l})$ resulted in water quality changes similar to those of the neomycin sulphate. Total ammonia nitrogen rose to a peak of $0.88 \mathrm{mg} / 1$ on day 6 and then gradually declined. Nitrite-nitrogen remained stable. Nitrate-nitrogen rose during treatment reaching $13.5 \mathrm{mg} / \mathrm{l} \mathrm{NO}_{3}^{-}-\mathrm{N}$ on day 18 (Fig.1). 

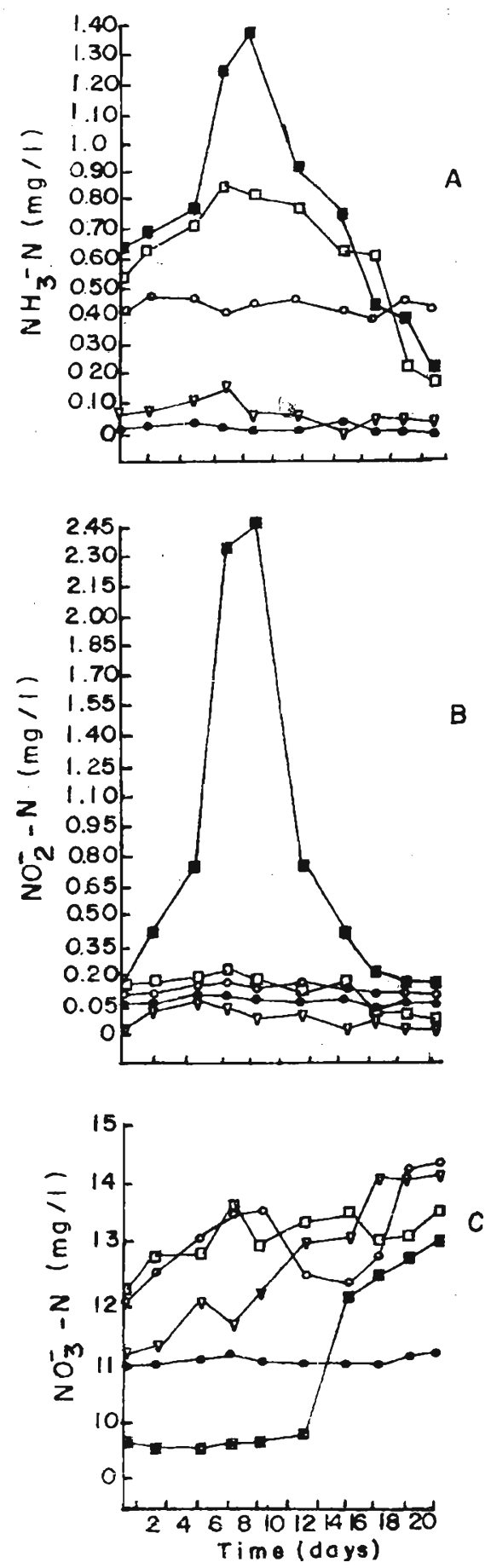

Figure 1: Changes in (A) total $\mathrm{NH}_{3}^{-} \mathrm{N},(\mathrm{B}) \mathrm{NO}_{2}^{-}-\mathrm{N}$ and (C) $\mathrm{NO}_{3}^{-}-\mathrm{N}$ concentrations in flasks treated with various antimicrobial agents: Control (@); gentamycin sulphate $(\nabla)$; chloramphenicol (o); methylene blue ( $\square$ ) and neomycin sulphate ( $\mathbf{\square})$. 
Treatment with chloramphenicol (13.3 mg/l) resulted in higher concentrations of total-ammonia nitrogen. The nitrite-nitrogen values did not differ significantly ( $p>0.05$ ) from those of controls. Nitrate-nitrogen rose immediately during treatment reaching $14.2 \mathrm{mg} / \mathrm{l}$ on day 18.

Survival studies for pure cultures of the three bacterial isolates were conducted with the antimicrobial agents. The data for survival of the three bacteria as measured indirectly on agar plates are plotted in Fig. 2.

Gentamycin sulphate did not inhibit the growth of Nitrosomonas. However, it had some inibitory effect on Nitrobacter and more on Aeromonas hydrophila. Chloramphenicol caused marked inhibition of the growth of all three organisms. With neomycin sulphate, the numbers of Nitrobacter and Nitrosomonas declined rapidly during treatment. This agent had a strong effect on Aeromonas hydrophila. Methylene blue caused marked inhibition of the growth of Nitrosomonas, Nitrobacter and Aeromonas hydrophila.

A significant $(\mathrm{p}<0.05)$ negative correlation was found to occur with $\mathrm{NH}_{4}^{+}-\mathrm{N}$ and $\mathrm{NO}_{2}^{-}-\mathrm{N}$; these parameters demonstrated the greatest influence with respect to the survival of the three bacteria in flasks treated with antimicrobial agents.

\section{DISCUSSION}

Some of the antimicrobial agents decreased in the concentrations of ammonia, nitrite and nitrate. The $\mathrm{pH}$ values in the treated culture flasks did not differ significantly from those of the control.

Gentamycin sulphate did not inhibit the growth of Nitrosomonas but slightly inhibited Nitrobacter and more so A. hydrophila. These results corroborate the observation of Bower \& Turner (1981) that gentamycin sulphate has no significant effect on nitrification in a recirculating aquatic system.

Chloramphenicol at a concentration of $13.3 \mathrm{mg} / \mathrm{inhibited}$ all three organisms. The results are consistent with those of Levine Meade (1976) who reported $48 \%$ inhibition in mixed culture of nitrifiers treated with 12.5 and $15.0 \mathrm{mg} / \mathrm{l}$ chloramphenicol. They also agreed with the report of Collins et al. (1976) who found no inhibition of ammonia oxidation in fresh water aquaria by $50 \mathrm{mg} / \mathrm{l}$ chloramphenicol.

Neomycin sulphate at $66.7 \mathrm{mg} / \mathrm{l}$ inhibited nitrite oxidation and the numbers of Nitrobacter declined rapidly. This antimicrobial agent slightly inhibited ammonia oxidation and the numbers of Nitrosomonas. However, it has severe effects on Aeromonas hydrophila. This suggests that neomycin sulphate is toxic 

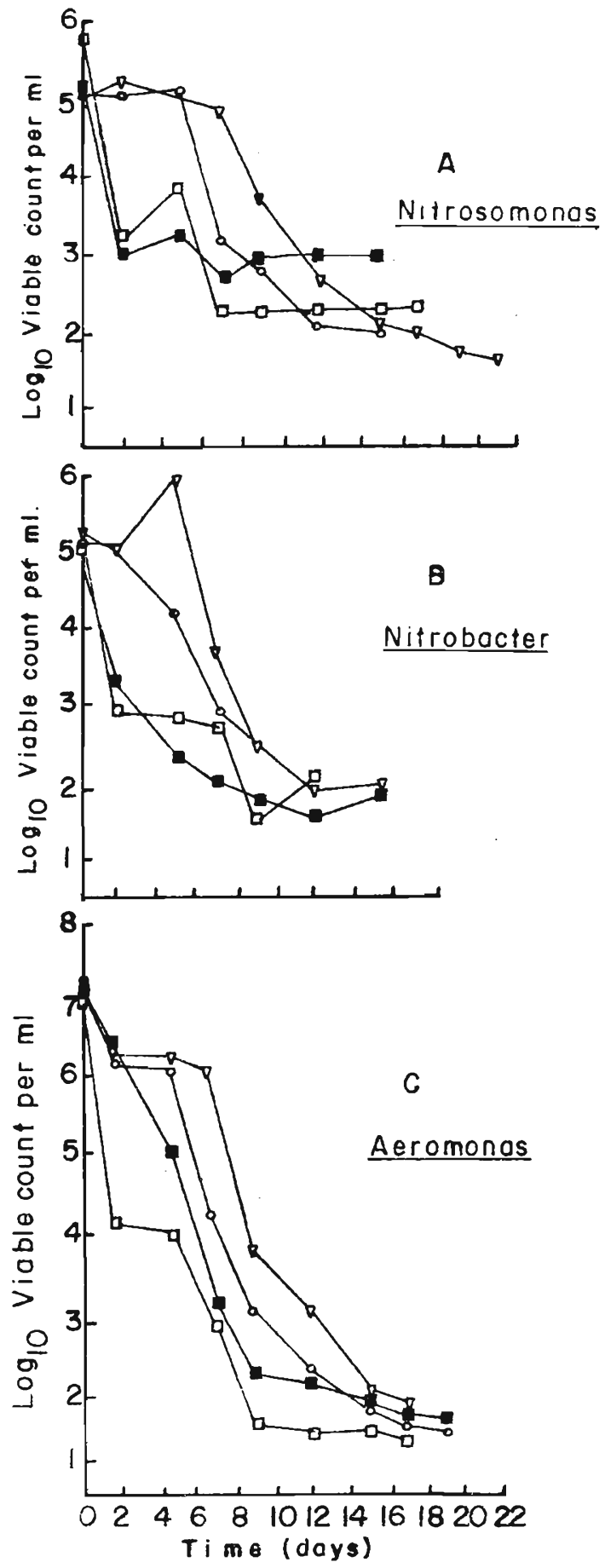

Figure 2: Effects of various antimicrobials on the survival of Nitrosomonas (A), Nitrobacter (B) and Aeromonas hydrophila (C). Gentamycin sulphate $(\nabla)$;

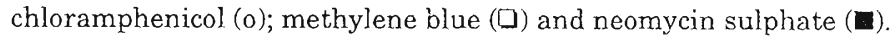


to the three isolates. These results corroborate the observation of Bower \& Turner (1982) that similar treatment dosage inhibited nitrite oxidation and slightly inhibited ammonia oxidation in fresh water aquaria.

In this study, $8 \mathrm{mg} / \mathrm{l}$ methylene blue caused marked inhibition of the growth of Nitrosomonas, Nitrobacter and A. hydrophila and thus ammonia and nitrite oxidation in fresh water aquaria. These results are in consonance with those of Levine \& Meade (1976) that $2.0 \mathrm{mg} / \mathrm{l}$ methylene blue inhibits nitrification by $92 \%$ in culture, and they also agree with the observation of Collins et al. (1976) that $5 \mathrm{mg} / \mathrm{l}$ methylene blue inhibits ammonia oxidation in freshwater aquaria.

With the exception of gentamycin sulphate, nitrogen transformation was markedly inhibited in all the experimental flasks treated with other antimicrobial agents. Increase in ammonia with stable nitrate levels indicated that nitrogen transformation had ceased. Elevated levels of nitrite lasted for about 14 days in all the flasks until the nitrite was probably converted to nitrate by the recovery of few surviving Nitrobacter which oxidized nitrite to nitrate. The pattern of water quality changes is similar to that described by Collins et al. (1976) in an unconditioned aquatic recirculating system indicating that both Nitrosomonas and Nitrobacter as well as other bacteria in the system were inhibited or killed by the antimicrobial agents.

The results of the experiment clearly demonstrate that the majority of the generally accepted antimicrobials for disease treatment in aquaculture systems can have adverse effects on nitrogen transformation in those systems since they are highly toxic to Nitrosomonas and Nitrobacter. Their inhibition leads to the accumulation of ammonia and or nitrite, substances that can be highly toxic to aquatic animals. The use of methylene blue, neomycin sulphate, or chloramphenicol is, therefore, not recommended for the control of diseases in such culture ponds. The results show clearly that gentamycin sulphate is the preferred agent for the treatment of $A$. hydrophila infections in fish culture ponds in Nigeria since it has minimal effect on nitrogen cycling in the fresh-water ecosystem.

\section{Acknowledgement}

We thank C.N. Duru and the staff of Duru Fish Farm, Awo-Omamma, Imo State, Nigeria, for their cooperation during the sampling of fish ponds. This work was supported by the International Foundation for Science (IFS) grant number A/1318-3 awarded to the principal author. 


\section{References}

1. Fischer E. (1972). Seasonal changes in the number of nitrogen cycle bacteria in bottom sediments of a pool. Polskie Archiwum Hydrobiologii. 19: 37-52.

2. Okpokwasili G.C., Ogbulie J.N., Eleke F.N. \& Okpokwasili N.P. (1996) . Substrate specificity of heterotrophic microorganisms in tilapia culture ponds. International Journal of Biochemiphysics (in press).

3. Horsley R.W., Roscoe J.V. \& Talling I.B. (1982). Nitrate reduction by Pseudomonas spp. Antagonism by fermentative bacteria. Journal of Applied Bacteriology 52: 57-66.

4. Trust T.J. \& Sparrow R.A.H. (1974). The bacterial flora in the alimentary tract of freshwater salmonid fishes. Canadian Journal of Microbiology 20: 1219-1228.

5. Okpokwasili G.C. \& Obah O.O. (1991). Relationship between water quality and bacteria associated with the brown patch disease of tilapia fingerlings reared in tropical freshwater culture ponds. Journal of Aquaculture in the Tropics 6:157-172.

6. Okaeme A.N. (1989). Bacteria associated with mortality in tilapia (Heterobranchus bidorsalis and Clarias lazera) in indoor ponds. Journal of Aquaculture in the Tropics 4:143-146.

7. Okpokwasili G.C. \& Okpokwasili N.P. (1994). Virulence and drug resistance patterns of some bacteria associated with "brown patch" disease of tilapia. Journal of Aquaculture in the Tropics 9: 223-233.

8. Van Duijn C. (1973). Diseases of fishes. 3rd edition. Charles C. Thomas, Springfield, IL. 372p.

9. Bullock G.L., Conroy D.A. \& Snieszko S.F. (1971). Bacterial diseases of fishes. TFH publications, Neptune City, N.J. 151p.

10. Collins M.T., Gratzek J.B., Daive D.L. \& Nemetz T.G. (1976). Effects of antibacterial agents on nitrification in an aquatic recirculating system. Journal of the Fisheries Research Board of Canada 33: 215-218.

11. Levine G. \& Meade T.L. (1976). The effects of disease treatment on nitrification in closed system aquaculture. In: J.W. Avault, jr. (Editor). Proc. 7th Ann. Meet.World Maricults. Soc. Louisiana State Univ., Baton Rouge, L.A. pp. 483-493. 
12. Bower C.E. \& Turner D.T. (1982). Effects of seven chemotherapeutic agents on nitrification in closed seawater culture system. Aquaculture 29:331-345.

13. Okpokwasili G.C. \& F.N. Eleke (1997). Effects of fish feeds on the activity and survival of Aeromonas hydrophila and nitrifying bacteria in a tilapia fish pond. Tropical Freshwater Biology (in press).

14. Spotte S. (1970). Fish and invertebrate culture: water management in closed system. John Wiley, New York. 145pp.

15. Water analysis handbook. (1985). Hach Company, Loveland, Colorado. $346 \mathrm{p}$.

16. Colwell R.R. \& Zambruski M.S. (1972). Methods in aquatic microbiology. University Park Press, Baltimore. pp. 251-288.

17. Shotts E.B. \& Rimler R. (1973). Medium for the isolation of Aeromonas hydrophila. Journal of Applied Microbiology 26: 550-553.

18. Kaper J.B., Seidler R.I., Lockman H. \& Colwell R.R. (1979). A medium for the presumptive identification of Aeromonas hydrophila and Enterobacteriaceae. Applied Environmental Microbiology 38: 1023-1026.

19. Buchanan R.E. \& Gibbons N.E. (eds) (1974). Bergey's Manual of determinative bacteriology. 8th edition. Williams and Wilkins, Baltimore. $1268 \mathrm{p}$.

20. Morgan J.A.W., Cranwell P.A. \& Pickup R.W. (1991). Survival of Aeromonas salmonicide in Lake water. Applied Environmental Microbiology 57: 1777 1782. 